\title{
Indonesia: Threats to physical urban water problems
}

\author{
Andi Besse Rimba ${ }^{1}$, Putu Edi Yastika ${ }^{2}$ \\ ${ }^{1}$ United Nations University Institute for the Advanced Study of Sustainability (UNU-IAS), 5-53-70, Shibuya-Ku, Tokyo 150-8925, \\ Japan (imba@unu.edu) \\ ${ }^{2}$ Graduate School of Science and Technology for Innovation, Yamaguchi University, 2-16-1 Tokiwadai, Ube-shi, Yamaguchi 755- \\ 8611, Japan (eyastika@yamaguchi-u.ac.jp).
}

\begin{abstract}
The world population percentage placed Indonesia in fourth place of the highest populated countries in the world. The majority of Indonesians live in an urban area. Java Island is the highest populated island in Indonesia, especially in Jakarta, Semarang, and Surabaya. This study showed the flood depth in these three cities, which has become a yearly threat during the rainy season. At the same time, another problem due to water withdrawal was analyzed. Land subsidence has occurred due to simultaneous water withdrawal and overload of alluvial soil due to land-use conversion. A remote sensing data and geographical information system (GIS) took account in this analysis to achieve the aim of this study. The hydraulic model was created to produce a flood depth map, and differential interferometric synthetic aperture radar (DInSAR) technique generated a land subsidence map. This study aims to show the problem in these three cities related to water in urban areas. This study found that all study areas had a severe risk of flood and land subsidence. Semarang received more threats to flood and land subsidence comparing to the other cities.
\end{abstract}

\section{Background}

In recent years, the world, especially developing countries, has become progressively conscious of the vast risks that environmental problems pose to the functionality of city areas. Environmental problems, climate change, and rapid urbanization are likely to continue to lead to increasing water demand and more severe rainstorms and flash floods, as well as land subsidence due to water withdrawal.

The damage triggered by floods in urban areas has become more serious around the world because of high population density and excessive property rates. Hydroclimatology is not the only factor for causing floods, it can be caused by human activity for example unorganized land management [1]. Width area of paved street and high land conversion from green area to builtup area are typical of urban area, which enlarge impermeable area, lead large surface runoff, and reduce water catchment. Thus, poor land use management and development instigate city area vulnerable to flood when combined with the hydro and climate factors.

Population growth and the activities linked with it lead to a continuous rise in the need for usable water, which is one of the main challenges of water management. The withdrawal of water is mainly used by sectors such as agriculture, industries, the domestic sector, and so on. Domestic needs and infrastructure requirements dominate the water demand in large cities. For much of the 20th century, groundwork developments were made to increase water withdrawal from rivers and groundwater reserves to meet the demands of an evergrowing population. Land subsidence occurs by natural and anthropogenic process. Land subsidence by human activity can be divided into two processes. Firstly, young alluvial soil receives pressure from construction [2].
Second, drying soil by drainage for agriculture force the sinking of water level [3].

Indonesia is one of the developing countries in Southeast Asia, which has more problems when compared with developed countries, but despite this, they have to survive the environmental issues. First, they have to be able to recognize their problems, and second, they have to develop the country by strengthening their socioeconomic factors. They deal with major urban environmental problems due to fast sprawl and growth. Furthermore, climate change assigns another pressure. Indonesia is vulnerable to physical urban water due to problems with land use and groundwater withdrawal.

In this study, two major problems with water in big cities were investigated: flood and land subsidence in Jakarta, Surabaya, and Semarang. The triggers of these issues were high number of population. High-populated area use more water and withdraw water to fulfill their demand from groundwater. Furthermore, high populated area covers soil surface and causes low infiltration rate. This study showed the distribution area of land subsidence and flood depth prediction in three highpopulated cities in Indonesia.

\section{Data and methodology}

This study employed database both of primary and secondary data. The primary data was collected during field survey in the three-research locations. The secondary data were gathered various website and institutions. Two mains modelling were created in this study, i.e., flood modelling to extract flood depth by FLO-2D software and GMTSAR on Linux Ubuntu to produce rate of land subsidence in three cities from 2015

* Corresponding author: rimba@unu.edu/ 
to 2017. Remote sensing data took into account for this modelling. Landsat image data was utilized to extract land use map for flood modeling, Sentinel-1 data for calculating land subsidence rate, and DEM data as an input for flood modelling and remove topography effect for land subsidence model. Generated maps from two models were overlaid to show the spatial distribution of flood inundation and land subsidence without calculating the statistic relationship between them.

\subsection{Flood modelling}

The flood model was designed to calculate streamflow circumstances, for example flow depth and velocity, the inundation area and hazard map. FLO-2D is essential tools to create a flood model for this research. Firstly, digital elevation model (DEM) was utilized to produce the watershed boundary by using GIS software. Range of grid element followed the standard range of the software ( $15 \mathrm{~m}$ to $150 \mathrm{~m}$ ) [4]. Grid interpolation was generated to assign an elevation for each grid element. Climate modeling, hydrological model, land use, and soil information were utilized as the input for the FLO-2D flood hazard simulation as shown in Fig.1.

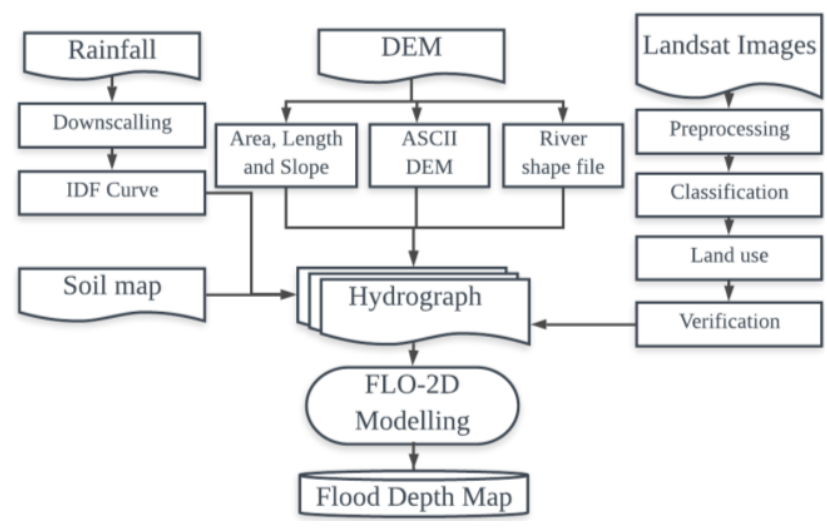

Fig. 1. Flowchart of flood depth model

Rainfall data was downscaled from CMIP5 data and verified by Meteorology, Climatology, and Geophysical Agency to generate Intensity-durationfrequency (IDF). IDF curve can be utilized to estimate the extreme discharge for predicting flood event and return. DEM data employed from the U.S. Geological Survey National Geospatial (USGS) https://earthexplorer.usgs.gov/ to extract area, length, slope of study area. Furthermore, ASCII DEM and river shape file were generated from DEM data by applying GIS software. Landsat image was pre-processed and classified to produce land use data. Land use and soil map have an important role to calculate manning's $n$ value of surface run-off. In this study, we used land use as source to produce flood map. Settlement area increases the run off and reduce the infiltration rate, those things influences the manning's $\mathrm{n}$ value. By using this method, velocity and inundation maps could be generated. However, in this study, we extracted only flood depth map because combination of velocity and depth usually for hazard study. Mapper software was used for post-processing and GIS software for the model layout in the research areas. Figure 1 shows the flowchart of flood depth model by FLO-2D.

\subsection{Land subsidence}

Differential Interferometric Synthetic Aperture Radar (DInSAR) method and data from Global Positioning Systems (GPS) are widely used to monitor land subsidence due to natural and anthropogenic processes[5]. The DInSAR technique was applied to Sentinel-1 data acquired in 2015 and 2017 from the European Space Agency (ESA) to measure land deformation in three big cities of Indonesia (Jakarta, Semarang, and Surabaya). Figure 2 shows the flowchart of DInSAR process by utilizing GMTSAR software. Three pairs of SAR were collected for three cities, i.e., path numbers 98, 127, and 54 for Jakarta, Semarang, and Surabaya, respectively. Accordingly, three interferograms were created, one interferogram for each city. An ellipsoid model (EGM98) and ALOS Global DEM $30 \mathrm{~m}$ (ALOS-GDEM) were employed from the Japan Aerospace Exploration Agency (JAXA) to eliminate the flat earth effect and the topographic phase component, respectively. All interferograms were filtered using the Goldstein filter to suppress noises. Thus, the Minimum Cost Flow (MCF) approach was operated to unwrap the differential phase interferogram. Several ground control points (GCPs) from previous researches were selected and applied to the polynomial fitting model and used to reduce some remaining errors in the unwrapped phase. Finally, LOS displacement maps were generated, and based on them, subsidence maps were derived with a $30 \mathrm{~m}$ spatial resolution. This model was applied to all research areas.

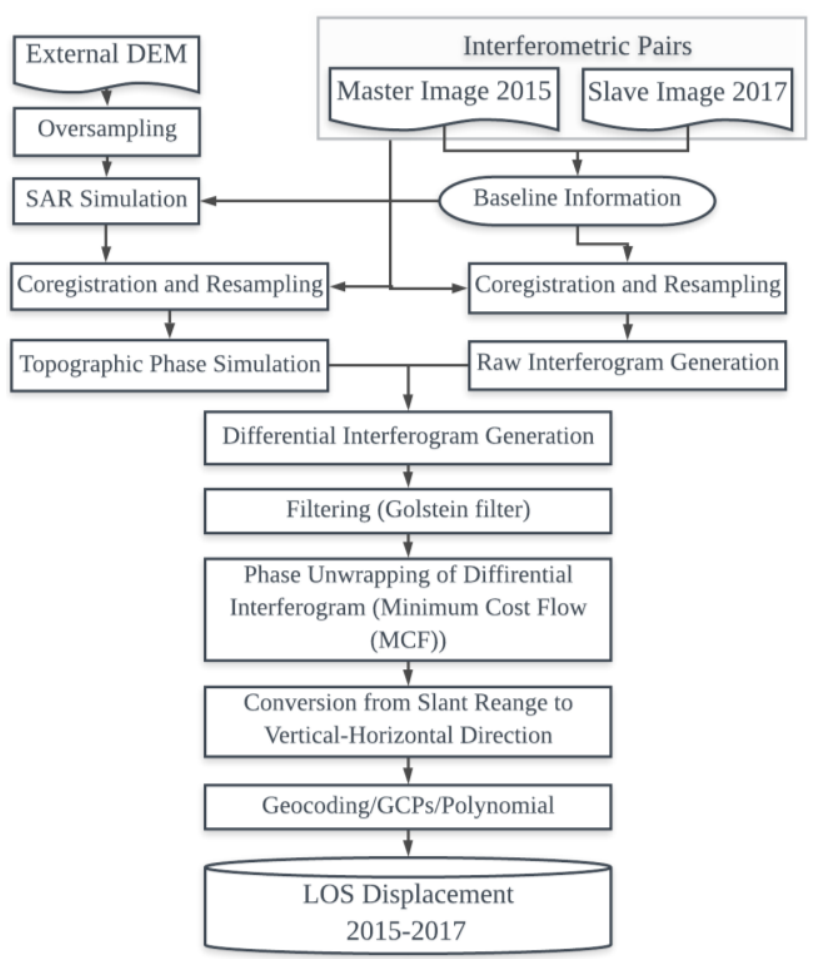

Fig. 2. Flowchart of DInSAR 


\section{Research location}

The research area is located on Java Island. Most of the population of Indonesia lives on this island and inhabit in coastal area for example Jakarta, Surabaya, and Semarang [6]. We selected three cities, namely Jakarta, Semarang, and Surabaya, whose major soil type was alluvial and which received pressure from the local environment where land was used mainly for residential and industrial purposes. The location of the research areas are shown in Fig. 3.
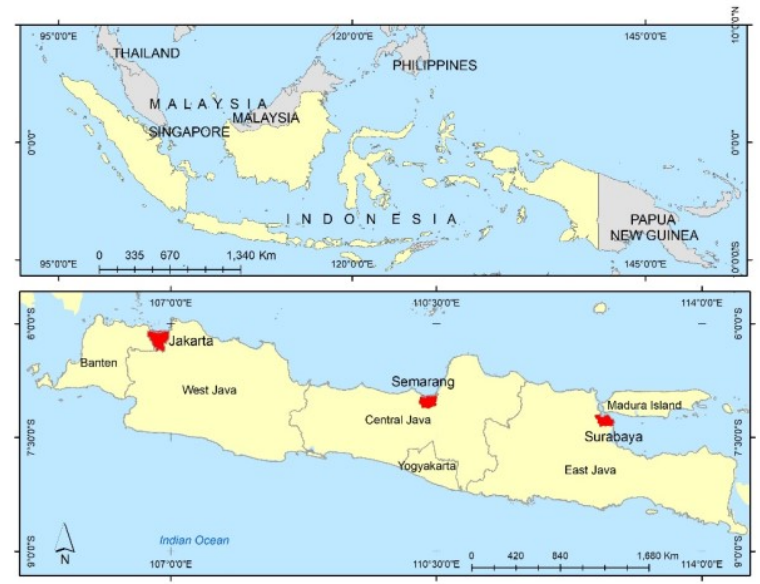

Fig. 3. Study areas

\section{Results and discussion}

\subsection{Jakarta}

Jakarta suffered major floods in 1996, 2002, 2007, 2013, 2014 and 2015. Flood modeling has been done in the Ciliwung River, as shown in Fig. 4 (the main river in Jakarta where its upstream is located on Panrango Mountain). The catchment area is $382.6 \mathrm{~km}^{2}$ with 117 $\mathrm{km}$ of length. The Ciliwung River has a significant contribution to the Jakarta flood. The flood model was created by utilizing $90 \mathrm{~m}$ of DEM data from the Shuttle Radar Topography Mission (SRTM). The inflow and outflow of the river were decided from field data. The hydraulic model of the Ciliwung River ran for 72 hours by utilizing water level data and employing FLO-2D software. A maximum water depth of up to one meter was captured in the areas around Pasar Minggu, Jaga Karsa and Pancoranmas. Heavy rainfall was the primary trigger of the flooding; however, the rapid population growth was causing the flood risk to escalate.

Land subsidence may be one of the leading factors that cause urban flooding in Jakarta [10]. However, according to Figure 4, the flood depth varies according to the different rates of land subsidence. Future studies and temporal flood analysis are required to prove the relationship between floods and land subsidence.

Flood and land subsidence are aggravated by population. High populated area reduces the infiltration rate and accelerate surface flow. Furthermore, city residents withdraw ground water to fulfill their water demand. Moreover, high population density causes heavy load on the ground surface. According to data from Statistical agency of DKI Jakarta, Number of population increased 860,000 people from 2010 to 2018 as shown in Table 1.

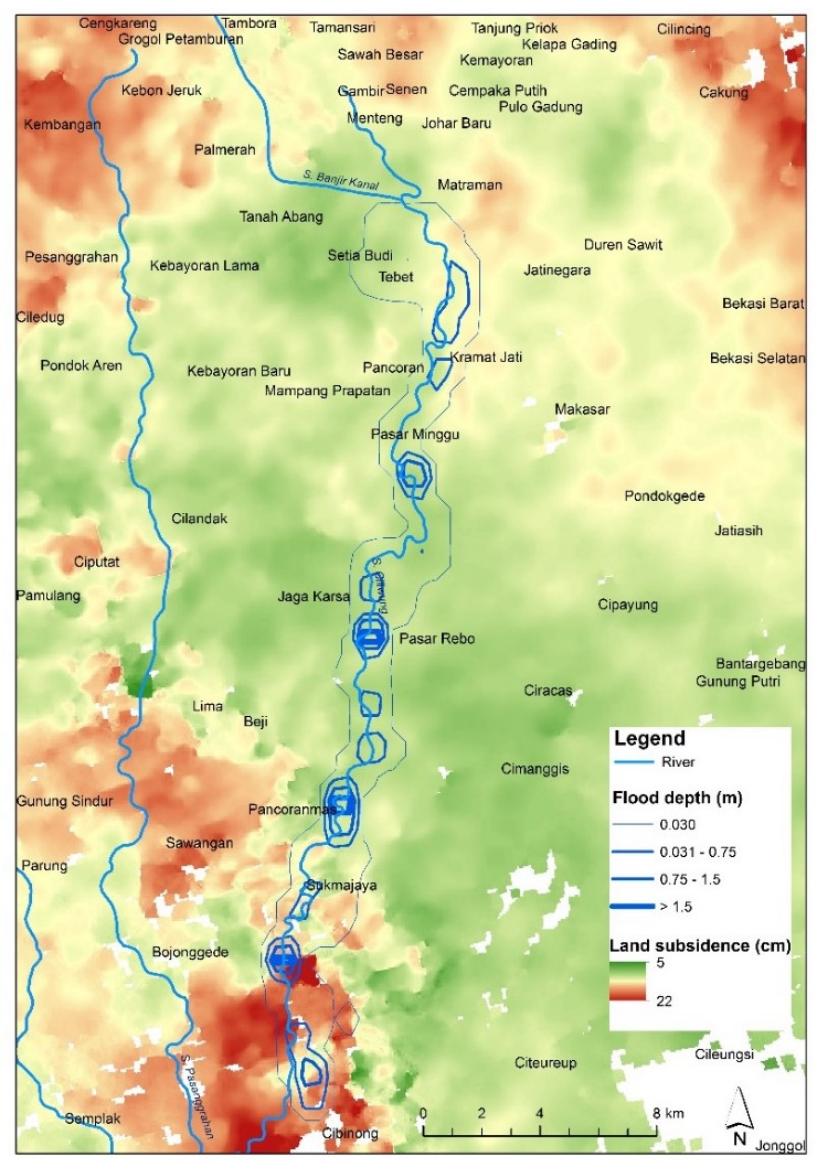

Fig. 4. Flood depth and land subsidence in Jakarta

Table 1. Number of Jakarta population

\begin{tabular}{|l|r|r|}
\hline \multicolumn{1}{|c|}{ Sub-district } & $\begin{array}{c}\text { Population } \\
(2010)\end{array}$ & \multicolumn{1}{c|}{$\begin{array}{c}\text { Population } \\
(2018)\end{array}$} \\
\hline The thousand island & 21080 & 24130 \\
\hline South Jakarta & 2062230 & 2246140 \\
\hline East Jakarta & 2693900 & 2916020 \\
\hline Central Jakarta & 902970 & 924690 \\
\hline West Jakarta & 2281950 & 2559360 \\
\hline North Jakarta & 1645660 & 1747310 \\
\hline DKI Jakarta (Total) & 9607790 & 10467630 \\
\hline
\end{tabular}

Sources:BPS (https://jakarta.bps.go.id/site/resultTab)

The demand for water increases with the increasing population, and the demand in the settlement is mostly for domestic water, which has increased to approximately 51 million $\mathrm{m}^{3}$ in Jakarta over the past decade. Non-domestic water is used for industrial production. Water from the Citarum River is the primary water resource; it is purified and used to supply domestic water in Jakarta, and the groundwater supports the industrial activity [8]. The withdrawal of groundwater leads to the subsidence of land [5], [9]. The DInSAR results (Fig.4) show that, between July 2015 and July 
2017, the subsidence rate in Jakarta was 0.5 to $22 \mathrm{~cm}$, and that most considerable land subsidences occurred in the Panjaringan, Kalideres, Kembangan, Clincing, and Cakung areas.

Furthermore, Jakarta is the capital city and the biggest city in Indonesia. It covers $663 \mathrm{~km}^{2}$ and 6,978 $\mathrm{km}^{2}$ of land and sea area, respectively. This city receives high water pressure compared to other cities in Indonesia. Jakarta's population increases year by year by approximately $9 \%$ of the built-up area in Jakarta from 2000 to 2010 and $18.6 \%$ of the population [7]. In 2013, Jakarta had 10,000 Ha (9\%) of green area, and this area had reduced by $20 \%$ from the original area in 2007 $(33,467 \mathrm{Ha})[8]$. Built-Up increment means reducing the water catchment area that causes surface runoff during the rainy season and increasing flood threats. The percentage of land use (built-up, green area and open area) in this study took a role in flood modelling, it influenced the manning's n value.

\subsection{Semarang}

Semarang is the capital of Central Java province and located in the coastal area. According to its population, Semarang is categorized as the fifth-largest city in Indonesia. Semarang's landscape consists of two major categories. Semarang deals with several physical challenges, e.g., tidal floods, runoff floods, coastal abrasion, land subsidence, and a rise in sea-level, with seawater engulfing the coastal areas. Furthermore, the social problem has increased due to the urban sprawl in the city, which has now spread to suburban areas. Population growth in Semarang City is $0.83 \%$ every year, and the current statistical data shows 1.58 million people inhabiting an area of $373.30 \mathrm{~km}^{2}$ [11]. The settlement area has increased at the rate of $232 \mathrm{Ha} /$ year from 1980-2000 [12]. The development in the hilly areas in Semarang has led to a reduction in the green area that covers the upstream region. This development has increased the vulnerability of the upstream area to landslides and the middle and downstream areas to water shortage and flooding.

In the lowland area of Semarang City, two types of flooding usually attack: (a) tidal flooding due to the sea level rising which occurs mostly every day depending on ocean tides; (b) river flooding because the rainfall exceeds the flow maximum of the stream. Figure 5 shows the flood depth due to river flooding in two rivers (west and east flood canal). Modeling was done by Flo2D software with input from land use, water level and DEM. The model was run for 48 hours; the rivers were shorter than the river in Jakarta and Surabaya. The flood spread out quickly in Panggung Lor, Panggung Kidul, Kembangsari, Bangunharjo, and Gebangsari. Flood depth varied from $0.3 \mathrm{~m}$ to more than $2 \mathrm{~m}$.

Table 2 shows the number of population of Semarang City that increasing year by year. High population inhibits in the city; indeed, they need clean water to support their activity. Population is one of trigger of land subsidence due to heavy load of building and intensively water withdrawal. In the next 15 years, water demand would continue to increase by up to $200 \%$. However, non-pipeline distribution by non-PDAM parties (waterworks) contributes $31 \%$ of the total clean water, which comes from dug wells and pumped wells from groundwater [13]. However, land subsidence in Semarang is caused by several factors, such as water withdrawal and the heavy load of construction from industrial estates and economic activities in the coastal area. The soil type is sandy and clay, which is quickly depressed when overloaded by construction. The DInSAR result in this area is shown in Fig. 5. The land subsidence rate increased from approximately 12 to 22 $\mathrm{cm}$ between July 2015 and July 2017. The coastal area of Semarang (West and North Semarang) tends to experience higher land subsidence than the hilly area due to overload pressure population that associated with building and the intensive water withdrawal. GPS points verified this model with the assumption that the orientation point of GPS is located on stable ground. The others GPS points are relative to the orientation point.

Table 2. Number of Semarang population

\begin{tabular}{|l|r|r|r|r|}
\hline Name & \multicolumn{1}{|c|}{$\mathbf{2 0 0 8}$} & \multicolumn{1}{c|}{$\mathbf{2 0 1 0}$} & \multicolumn{1}{c|}{$\mathbf{2 0 1 2}$} & \multicolumn{1}{c|}{$\mathbf{2 0 1 5}$} \\
\hline Mijen & 48102 & 51806 & 55740 & 59950 \\
\hline Gunungpati & 64775 & 70379 & 74406 & 77829 \\
\hline Banyumanik & 121024 & 125182 & 127621 & 132438 \\
\hline Gajahmungkur & 61403 & 62310 & 63304 & 63707 \\
\hline South Smg & 85590 & 85584 & 83333 & 79472 \\
\hline Candisari & 80472 & 80450 & 79969 & 79492 \\
\hline Tembalang & 124814 & 131833 & 140982 & 155273 \\
\hline Pedurungan & 162063 & 167535 & 174775 & 178328 \\
\hline Genuk & 79172 & 84561 & 90150 & 97012 \\
\hline Gayamsari & 70359 & 74142 & 73273 & 74004 \\
\hline East Semarang & 82214 & 80951 & 79046 & 77959 \\
\hline North Smg & 126457 & 127049 & 127410 & 127720 \\
\hline Central Smg & 74414 & 73436 & 71933 & 70877 \\
\hline West Smg & 159307 & 160051 & 159632 & 158990 \\
\hline Tugu & 26803 & 27689 & 30171 & 31795 \\
\hline Ngaliyan & 107616 & 114114 & 119853 & 125130 \\
\hline $\begin{array}{l}\text { Semarang City } \\
\text { (Total) }\end{array}$ & 1474585 & 1517072 & 1551598 & 1589976 \\
\hline
\end{tabular}

Sources:BPS https://semarangkota.bps.go.id/site/resultTab

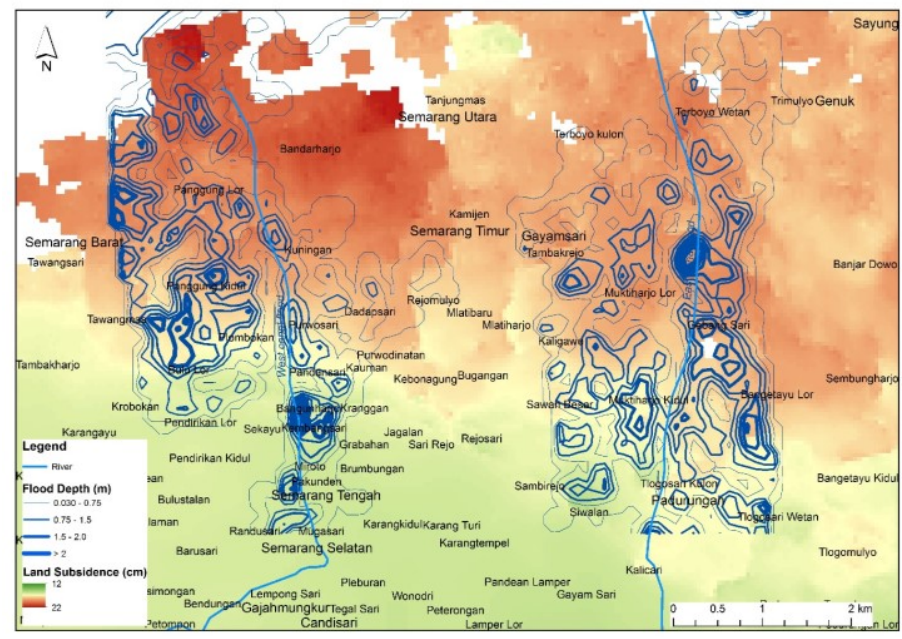

Fig. 5. Flood depth and land subsidence in Semarang 
Overlapping deep flood and high subsidence areas occurred in Gayamsari and East and West Semarang, as shown in Fig. 5. However, further study is required to prove the relation between these two water-related problems.

\subsection{Surabaya}

Surabaya is the second-largest city in Indonesia, placed on the east of Java island. The population of Surabaya City increases every year and reached 2.9 million people in 2015 , with a population growth rate of $0.55 \%$ in 2010-2015 and $0.52 \%$ in 2014-2015 [14]. Figure 6 shows number of population in Surabaya from 2011 to 2020. This population growth will increase water demand that automatically enhanced land subsidence and flood by increasing number of population.

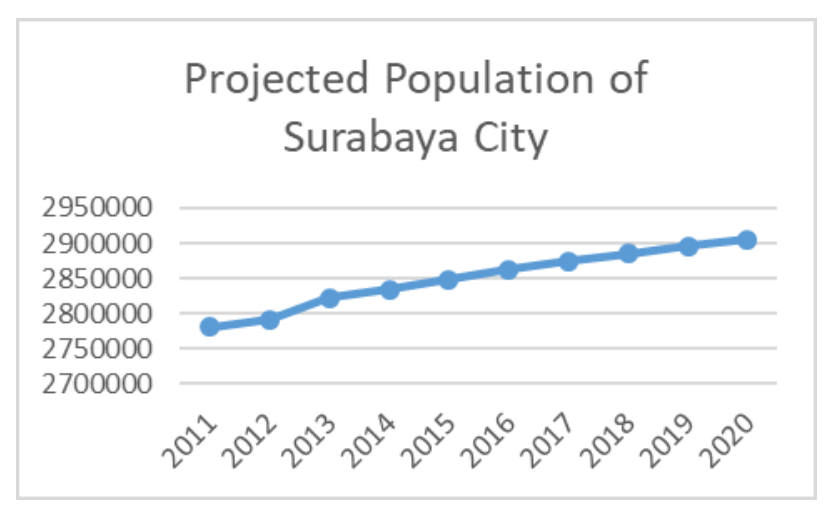

Fig. 6. Projected population of Surabaya City (Sources: BPS https://surabayakota.bps.go.id/site/resultTab)

This research repeated the method of Jakarta and Semarang case. It was conducted to analyze the performance of flood depth in the Brantas River in Surabaya City. The river has two branches, i.e., the Surabaya and the Porong River. SRTM and water level data were used to run this model. We ran 72 hours of flood model, as shown in Fig. 7. The flood depth is up to more than $1.5 \mathrm{~m}$, especially in the area around Taman and Gayungan.

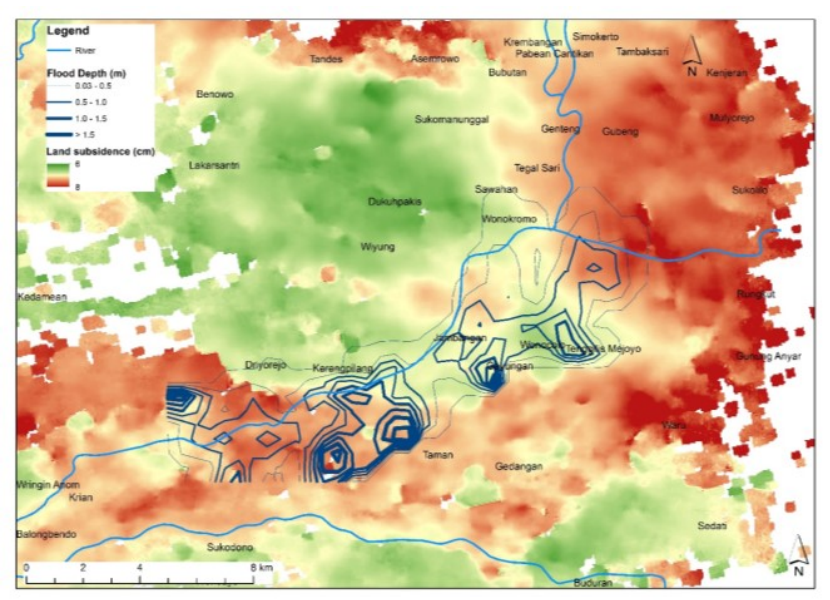

Fig. 7. Flood depth and land subsidence in Surabaya
The increasing deep groundwater exploitation in urbanized areas is causing land subsidence in big cities as shown in these study areas. Less coverage of pipe water service and weak water regulation led the ground water consumption. Fossil ground water is non rechargeable and gradually reduced. It caused the rapid sinking of groundwater and land subsidence in the big cities [17]. However, land subsidence in Surabaya is lower than that in Jakarta and Semarang. According to DInSAR analysis, the land subsidence rate in Surabaya was $6 \mathrm{~cm}$ to $8 \mathrm{~cm}$ from July 2015 to July 2017. The clean water source is from the Surabaya River (95\%). In the rainy season, the discharge rate from the Surabaya River is $40 \mathrm{~m}^{3} / \mathrm{sec}$, whereas during the dry season, the discharge rate decreases to $20 \mathrm{~m}^{3} / \mathrm{sec}$. This number is still sufficient to meet the water demand in Surabaya to promote less groundwater withdrawal. It can be a reason for the low subsidence level as compared to other big cities in Indonesia. Nevertheless, the Surabaya government should pay attention to water demand in the future.

Land subsidence and flooding in Surabaya show a lower rate than those of the other two cities in Fig.7. However, this is still an interesting study to conduct in the future to integrate flooding and land subsidence, especially in the downstream of the Brantas River.

\subsection{Field survey}

Figure 8 shows the condition of the research area. Figure $8 \mathrm{a}$ is the Ciliwung River close to Manggarai Bridge, which is a slum area. Figure $8 \mathrm{~b}$ is an elite residential area in Surabaya; however, it experienced a flood in early 2019. Figure 8c and $8 d$ are flooding areas in Semarang, which is located in the subsidence area. All these areas were experiencing land subsidence and counted as the flood-prone areas.

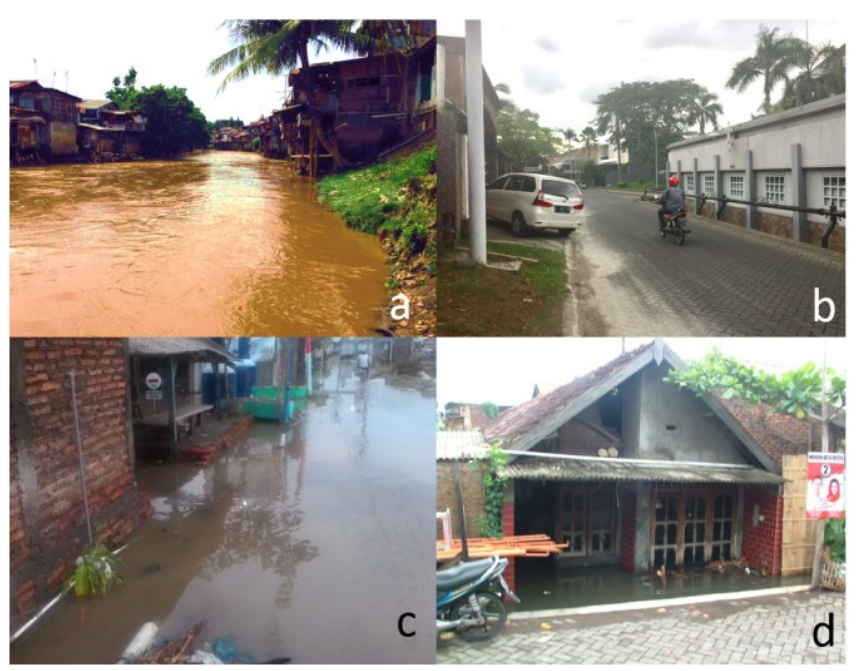

Fig. 8. (a) Ciliwung River, Jakarta (source : WUI-UNU), (b) Citra Land Surabaya (source: field survey), (c and d) Flood area in subsidence area, Semarang (source: field survey) 


\section{Conclusions}

a) Jakarta, Semarang, and Surabaya suffer from flooding and land subsidence. However, Further research should be conducted to measure the relationship between land subsidence and flooding by developing a more advanced method and adding more parameters. Since this study only shows the spatial distribution of flood and land subsidence, the future study will measure the relationship between them.

b) Comparing these three cities (i.e., Jakarta, Semarang and Surabaya); Semarang suffers from flooding more than other cities. The depth flood was up to more than $2 \mathrm{~m}$. Moreover, Semarang suffers from land subsidence more than other cities; its rate was up to $22 \mathrm{~cm}$ during the observation period.

c) Surabaya experienced low land subsidence, it may causes by sufficient surface water to support water demand and avoids excessive use of groundwater.

d) The rapidly growing population influences water demands. Land subsidence is enhanced by increasing number of population that intensively withdraw groundwater. Population settlements reduce the infiltration rate/enlarge impermeable area, lead large surface runoff, and reduce water catchment.

\section{Acknowledgements}

The financial and administrative supports were received from Kurita Foundation and JSPS. The data were downloaded from the European Space Agency (ESA), the Japan Aerospace Exploration Agency (JAXA), and USGS. Many thanks are extended to those agencies, and thanks for the support from CReSOS-Udayana Univerisity, The University of Tokyo, Yamaguchi University, United Nations University (Water Urban Initiative and Water for Sustainable Development project), Bandung Institute of Technology and Environmental Technology and Management Conference (ETMC 2019).

\section{References}

[1] Y. Lee and S. D. Brody, "Examining the impact of land use on flood losses in Seoul, Korea," Land use policy, vol. 70, no. November 2017, pp. 500-509, 2018.

[2] P. S. J. Minderhoud, L. Coumou, L. E. Erban, H. Middelkoop, E. Stouthamer, and E. A. Addink, "The relation between land use and subsidence in the Vietnamese Mekong delta," Sci. Total Environ., vol. 634, pp. 715-726, 2018.

[3] D. L. Galloway, G. Erkens, E. L. Kuniansky, and J. C. Rowland, "Preface: Land subsidence processes," Hydrogeol. J., vol. 24, no. 3, pp. 547-550, 2016.
[4] I. Haltas, G. Tayfur, and S. Elci, "Twodimensional numerical modeling of flood wave propagation in an urban area due to Ürkmez dam-break, İzmir, Turkey," Nat. Hazards, vol. 81, no. 3, pp. 2103-2119, 2016.

[5] D. L. Galloway and T. J. Burbey, "Review: Regional land subsidence accompanying groundwater extraction," Hydrogeol. J., vol. 19, no. 8, pp. 1459-1486, 2011.

[6] Husnayaen et al., "Physical assessment of coastal vulnerability under enhanced land subsidence in Semarang, Indonesia, using multisensor satellite data," $A d v$. Sp. Res., 2018.

[7] R. L. Pangaribowo, "Dynamics of land - Use change in urban area in West Jakarta," IOP Conf. Ser. Earth Environ. Sci., vol. 106, no. 1, 2018.

[8] L. Pingping, “OPingping, L. (2015). Overview of Jakarta Water- Related Environmental Challenges, (04).verview of Jakarta WaterRelated Environmental Challenges," no. 04, 2015.

[9] H. Z. Abidin, H. Andreas, I. Gumilar, T. P. Sidiq, and Y. Fukuda, "Land subsidence in coastal city of Semarang (Indonesia): characteristics, impacts and causes," Geomatics, Nat. Hazards Risk, vol. 4, no. 3, pp. 226-240, 2013.

[10] I. R. Moe, S. Kure, M. Farid, K. Udo, S. Kazama, and S. Koshimura, "Numerical Simulation of Flooding in Jakarta and Evaluation of a Counter Measure To Mitigate Flood Damage," J. Japan Soc. Civ. Eng. Ser. G (Environmental Res., vol. 71, no. 5, p. I_29-I_35, 2015.

[11] Badan Pusat Statistik Kota Semarang, "Kota Semarang Dalam Angka Tahun 2018," Badan Pus. Stat. Kota Semarang, p. 153, 2018.

[12] Hariyanto, "The dangerous of landuse changing in Semarang," Geogr. Forum, vol. 18, no. 2, pp. 152-160, 2004.

[13] Semarang City Government, "Resilient Semarang: Moving Together towards a Resilient Semarang," 2016.

[14] Badan Pusat Statistik Kota Surabaya, "Surabaya Munacipality in Figures 2018,” Surabaya, 2018.

[15] T. Pindo, Residential Land use and Housing Development in Indonesia from the Perspective of Sustainable Urban Form. 2014.

[16] C. Susetyo, "Urban Flood Management In Surabaya City: Anticipating Changes in the Brantas River System,” p. 127, 2008.

[17] ADB, Asian Development Bank Indonesia Country Water assessment Indonesia Country Water assessment. 2016. 